\title{
Analiza opinii polskich specjalistów ochrony wzroku dotyczących osadów na soczewkach kontaktowych
}

\author{
Analysis of Polish eye care professionals' opinions about deposits on contact lenses
}

\section{Tomasz Suliński ${ }^{1,2}$, Jacek Pniewski}

Alcon Polska

${ }^{2}$ Wydział Fizyki, Uniwersytet Warszawski Dziekan: prof. dr hab. Dariusz Wasik

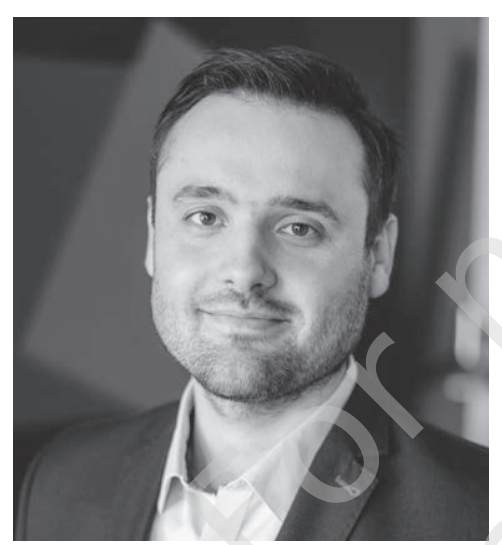

\section{N A J W A Ż N IE J SZE}

Polscy specjaliści ochrony wzroku uważają, że poszczególne soczewki

silikonowo-hydrożelowe mają różną odporność na osady lipidowe, która ma dla nich znaczenie w czasie wyboru produktu dla pacjenta.

\section{H I G H L I G H T S}

Polish eye care professionals believe that different silicone-hydrogel lenses vary in their resistance to lipid deposits, and this resistance is important to them when selecting a product for a patient.

\section{STRESZCZENIE}

Miękkie soczewki kontaktowe służące do korekcji ametropii są powszechnie używane na całym świecie. Jako wyrób medyczny powinny być dopasowywane i systematycznie oceniane na oku pacjenta przez specjalistów ochrony wzroku. Badanie kontrolne powinno obejmować ocenę osadów na soczewkach. Powszechne stosowanie soczewek silikonowo-hydrożelowych (Si-Hy) i ich tendencja do odkładania się złogów lipidowych wskazują, że specjaliści ochrony wzroku powinni zwracać szczególną uwagę na ten rodzaj osadów. Celem niniejszej pracy jest analiza opinii polskich specjalistów ochrony wzroku w zakresie osadów na soczewkach kontaktowych, ze szczególnym uwzględnieniem lipidów i soczewek Si-Hy. Dane zebrano od 103 polskich specjalistów ochrony wzroku poprzez ankietę internetową. Respondenci wskazali, że osady lipidowe najczęściej występują na soczewkach Si-Hy, a osady białkowe na soczewkach hydrożelowych. Niemal wszyscy ankietowani deklarują, że oceniają osady na soczewkach kontaktowych podczas wizyt kontrolnych, co pozwala wnioskować, iż jest to dla nich istotna część procesu doboru soczewek. Respondenci uważają, że poszczególne soczewki i płyny do ich pielęgnacji różnią się w kontekście ich interakcji z osadami lipidowymi. Parametry te powinny być brane pod uwagę w momencie wyboru produktu dla pacjenta. Specjaliści ochrony wzroku oczekują opisów odporności soczewek na powstawanie osadów lipidowych oraz skuteczności płynów pielęgnacyjnych w redukcji osadów lipidowych.

Słowa kluczowe: soczewki kontaktowe, osady na soczewkach kontaktowych, soczewki silikonowo-hydrożelowe, dyskomfort w soczewkach kontaktowych 


\section{ABSTRACT}

Soft contact lenses are used worldwide to correct ametropia. This medical device should be fitted and systematically evaluated on the patient eye by eye care professionals. The examination should include an evaluation of lens deposits. The widespread use of silicone hydrogel ( $\mathrm{Si}-\mathrm{Hy}$ ) lenses and their tendency to build up lipid deposits indicate that eye care professionals should pay special attention to this kind of deposits. This paper aims to analyze the opinions of Polish ECPs regarding deposits on contact lenses, particularly regarding lipids and Si-Hy lenses. Data were collected from 103 Polish eye care professionals through an online survey. Respondents reported that lipid deposits are most often present on Si-Hy lenses, and protein deposits occur most often on hydrogel lenses. Almost all of them declare that they evaluate deposits on contact lenses on follow-up visits, which concludes that this is an essential part of the lens selection process for them. Respondents believe that different lenses and lens care solutions vary in the context of their interaction with lipid deposits. These parameters should be considered at the time of product selection. Eye care professionals expect descriptions of lenses' resistance to lipid deposits, and care solution effectiveness in reducing lipid deposits.

Key words: contact lenses, contact lens deposits, silicone-hydrogel contact lenses, contact lens discomfort

\section{WSTĘP}

Soczewki kontaktowe są popularną metodą korekcji wad refrakcji oka stosowaną na całym świecie. Raport, zebrany z 24 światowych rynków na całym świecie, wskazuje, że specjaliści ochrony wzroku (ECPs, eye care professionals) najczęściej dopasowują soczewki miękkie (82\% dopasowań w 2020 r.), podczas gdy soczewki silikonowo-hydrożelowe (Si-Hy) stanowią 59\% dopasowań [1]. Soczewki kontaktowe działają $\mathrm{w}$ bezpośrednim kontakcie $\mathrm{z}$ okiem pacjenta, w związku z czym funkcjonują na jego powierzchni i są otoczone przez film łzowy. W skład filmu łzowego wchodzą woda oraz takie substancje, jak: mucyny, lipidy, białka i elektrolity. Główne składniki lipidowe łez (mol\%) to: ester cholesterolowy, ester woskowy i cholesterol [2]. W filmie łzowym wyselekcjonowano ponad 1,5 tys. białek [3]. Aktualne stanowisko opisuje film łzowy jako dynamiczną jednostkę funkcjonalną z różnymi przedziałami, zmieniając starą definicję trójwarstwowego filmu łzowego (mucyna, woda, lipidy) i wprowadzając koncepcję „przeplatających się warstw" [4, 5].

Podczas funkcjonowania w złożonym środowisku oka soczewki kontaktowe są narażone na gromadzenie endogennych osadów, zarówno białkowych, jak i lipidowych [6]. Stwierdzono, że soczewki Si-Hy gromadzą więcej lipidów w porównaniu z soczewkami hydrożelowymi, które z kolei gromadzą więcej białek [7, 8]. W związku z powyższym interakcje pomiędzy lipidami a soczewkami Si-Hy są bardzo istotne. W ostatnio opublikowanej pracy przeglądowej na ten temat Suliński i Pniewski zgłosili, że:

- Poszczególne materiały soczewek Si-Hy wykazują różne właściwości odnośnie do osadów lipidowych, co może wynikać ze specyficznych właściwości polimerów lub z obróbki ich powierzchni.

- Nie opracowano standardowej metody oceny ilości osadów lipidowych w soczewkach $\mathrm{Si}-\mathrm{Hy}$.
- Wpływ depozytów lipidowych, znajdujących się na soczewkach Si-Hy, na odpowiedź kliniczną pacjentów, a w szczególności ich wpływ na dyskomfort, nie jest w pełni poznany [9].

Rolą ECPs w procesie dopasowywania soczewek kontaktowych jest zapewnienie pacjentowi prawidłowego widzenia, komfortu i bezpieczeństwa. Wymagane są regularne wizyty kontrolne w celu oceny zarówno stanu zdrowia oczu pacjenta, jak i stanu soczewek, co obejmuje także ocenę osadów [10].

\section{CEL}

Celem niniejszej pracy jest analiza opinii polskich ECPs dotyczących osadów na soczewkach kontaktowych, ze szczególnym uwzględnieniem lipidów i soczewek $\mathrm{Si}-\mathrm{Hy}$.

\section{METODY}

Dane zebrano za pomocą ankiety internetowej. Kryteria uczestnictwa były następujące:

- wiek: co najmniej 18 lat

- świadoma zgoda na udział w badaniu

- potwierdzenie, że respondent jest odpowiedzialny w swojej pracy za dopasowywanie soczewek kontaktowych.

W sumie zebrano 104 odpowiedzi. Jeden z respondentów nie spełnił powyższych kryteriów, dlatego jego odpowiedzi nie zostały wykorzystane w opracowaniu. Ostatecznie $\mathrm{w}$ analizie uwzględniono dane pochodzące od 103 respondentów.

Ankietowani mieli za zadanie odpowiedzieć na pięć pytań demograficznych oraz 13 pytań związanych z tematem badania. 
Odpowiedzi zostały przesłane przez 73 kobiety i 30 mężczyzn. Średnia wieku wynosiła 34,64 roku, przy czym najmłodszy respondent miał 24 lata, a najstarszy 62 lata. Ankietowani deklarowali, że mają tytuł optyka $(\mathrm{n}=1)$, studenta optometrii $(\mathrm{n}=9)$, lekarza okulisty $(\mathrm{n}=15)$ lub optometrysty ( $\mathrm{n}=78$ ). Większość z nich praktykowała w dużych miastach (ryc. 1), a 59\% badanych specjalistów miało co najmniej 5-letnie doświadczenie w dopasowywaniu soczewek (ryc. 2).

\section{RYCINA 1 \\ Deklaracja dotycząca wielkości miasta, w którym respondenci prowadzą praktykę.}

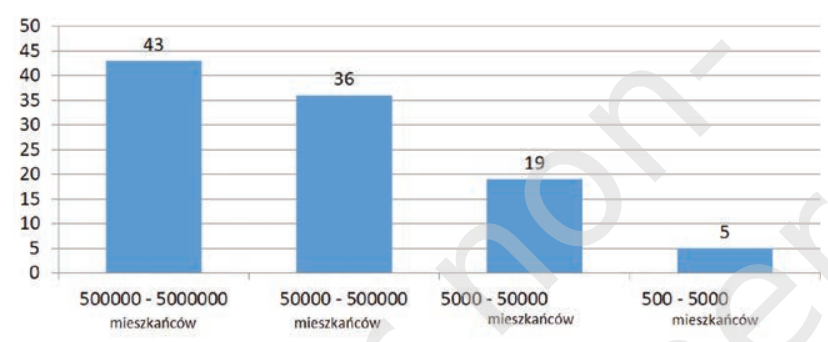

RYCINA 2
Doświadczenie ankietowanych specjalistów w dopasowywaniu
soczewek (w latach).

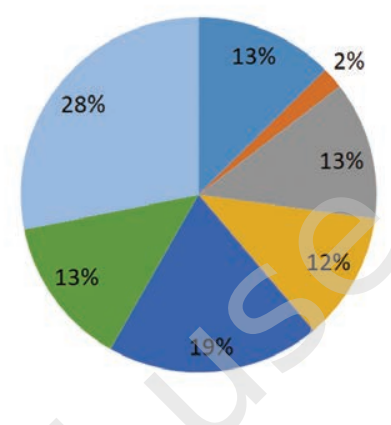

więcej niż 12 lat

- 11-12 lat

9-10 lat

7-8 lat

- 5-6 lat

3-4 lata

0-2 lata

\section{WYNIKI}

Tabela 1 zawiera listę pytań tematycznych zawartych w ankiecie.

\section{TABELA ( 1}

\section{Lista pytań i możliwych odpowiedzi użytych w ankiecie.}

\begin{tabular}{|c|c|c|}
\hline $\mathbf{N r}$ & Pytanie & Odpowiedzi do wyboru \\
\hline 1 & $\begin{array}{l}\text { Twoim zdaniem jakiego typu osady najczęściej pojawiają się na soczew- } \\
\text { kach hydrożelowych wielokrotnego użytku? }\end{array}$ & $\begin{array}{l}\text { - } \text { Białkowe } \\
\text { - Lipidowe } \\
\text { - Soczewki nie mają osadów } \\
\end{array}$ \\
\hline 2 & $\begin{array}{l}\text { Twoim zdaniem jakiego typu osady najczęściej pojawiają się na soczew- } \\
\text { kach silikonowo-hydrożelowych wielokrotnego użytku? }\end{array}$ & $\begin{array}{ll}\text { - } & \text { Białkowe } \\
\text { - } & \text { Lipidowe } \\
\text { - Soczewki nie mają osadów } \\
\text { - }\end{array}$ \\
\hline 3 & $\begin{array}{l}\text { Twoim zdaniem jakiego typu osady najczęściej pojawiają się na soczew- } \\
\text { kach hydrożelowych jednodniowych? }\end{array}$ & $\begin{array}{l}\text { - } \text { Białkowe } \\
\text { - Lipidowe } \\
\text { - Soczewki nie mają osadów } \\
\text { - Inne. }\end{array}$ \\
\hline 4 & $\begin{array}{l}\text { Twoim zdaniem jakiego typu osady najczęściej pojawiają się na soczew- } \\
\text { kach silikonowo-hydrożelowych jednodniowych? }\end{array}$ & $\begin{array}{ll}\text { - } & \text { Białkowe } \\
\text { - } & \text { Lipidowe } \\
\text { - Soczewki nie mają osadów } \\
\text { - Inne } \\
\end{array}$ \\
\hline 5 & $\begin{array}{l}\text { Czy na wizytach kontrolnych oceniasz osady na soczewkach kontakto- } \\
\text { wych? }\end{array}$ & $\begin{array}{l}\text { - Tak, zawsze } \\
\text { - Tak, ale tylko w niektórych przypadkach } \\
\text { - Tak, w większości przypadków } \\
\text { - Nie }\end{array}$ \\
\hline 6 & $\begin{array}{l}\text { Jaki wpływ na komfort użytkowania soczewek kontaktowych mają osady } \\
\text { lipidowe? }\end{array}$ & $\begin{array}{l}\text { - Zawsze prowadzą do dyskomfortu } \\
\text { - Czasami prowadzą do dyskomfortu } \\
\text { - Nie wpływają na komfort } \\
\text { - Poprawiają komfort }\end{array}$ \\
\hline
\end{tabular}




\begin{tabular}{|c|c|c|}
\hline 7 & $\begin{array}{l}\text { Jaki wpływ na jakość widzenia w soczewkach kontaktowych mają osady } \\
\text { lipidowe? }\end{array}$ & $\begin{array}{l}\text { - Zawsze powadzą do pogorszenia widzenia } \\
\text { - Czasami prowadzą do pogorszenia widzenia } \\
\text { - Nie wpływają na jakość widzenia } \\
\text { - Poprawiają jakość widzenia }\end{array}$ \\
\hline 8 & $\begin{array}{l}\text { Czy uważasz, że różne materiały soczewek silikonowo-hydrożelowych } \\
\text { cechuje różna odporność na osady lipidowe? }\end{array}$ & $\begin{array}{ll}\text { - } & \text { Tak, zdecydowanie } \\
\text { - } & \text { Tak, ale różnice są niewielkie } \\
\text { - Nie wiem } \\
\text { - Nie } \\
\end{array}$ \\
\hline 9 & $\begin{array}{l}\text { Czy odporność materiału soczewki na osady lipidowe ma dla ciebie zna- } \\
\text { czenie w procesie wyboru soczewki dla pacjenta? }\end{array}$ & $\begin{array}{l}\text { - Tak, zdecydowanie } \\
\text { - Tak } \\
\text { - Nie mam zdania } \\
\text { - Nie } \\
\text { - Nie, zdecydowanie }\end{array}$ \\
\hline 10 & $\begin{array}{l}\text { Czy soczewki powinny być opisywane przez producentów w zależności } \\
\text { od odporności na osady lipidowe? }\end{array}$ & $\begin{array}{l}\text { - } \text { Tak, zdecydowanie } \\
\text { - } \quad \text { Nak } \\
\text { - Nie mam zdania } \\
\text { - Nie } \\
\text { - Nie, zdecydowanie }\end{array}$ \\
\hline 11 & $\begin{array}{l}\text { Czy uważasz, że różne płyny do pielęgnacji soczewek kontaktowych } \\
\text { cechuje różna skuteczność redukowania osadów lipidowych? }\end{array}$ & $\begin{array}{l}\text { - Tak, zdecydowanie } \\
\text { - Tak, ale różnice są niewielkie } \\
\text { - Nie wiem } \\
\text { - Nie }\end{array}$ \\
\hline 12 & $\begin{array}{l}\text { Czy skuteczność redukowania osadów lipidowych ma dla ciebie znacze- } \\
\text { nie w procesie wyboru płynu pielęgnacyjnego dla pacjenta? }\end{array}$ & $\begin{array}{ll}\text { - Tak, zdecydowanie } \\
\text { - Tak } \\
\text { - Nie mam zdania } \\
\text { - Nie } \\
\text { - Nie, zdecydowanie } \\
\end{array}$ \\
\hline 13 & $\begin{array}{l}\text { Czy płyny pielęgnacyjne do soczewek powinny być opisywane przez } \\
\text { producentów w zależności od skuteczności redukowania osadów lipido- } \\
\text { wych? }\end{array}$ & $\begin{array}{l}\text { - Tak, zdecydowanie } \\
\text { - Tak } \\
\text { - Nie mam zdania } \\
\text { - Nie } \\
\text { - Nie, zdecydowanie }\end{array}$ \\
\hline
\end{tabular}

Pytania 1.-4. dotyczyły najczęściej występujących osadów na różnych typach soczewek kontaktowych. Zestawienie odpowiedzi zebrano w tabeli 2.
W pytaniach 6. i 7. badano opinie respondentów na temat wpływu osadów lipidowych na komfort i jakość widzenia (tab. 3).

\section{TABELA $(2$}

Zebrane wyniki ankiety (odsetek odpowiedzi i inne) dla pytań 1.-4.

\begin{tabular}{|c|c|c|c|c|}
\hline Tryb wymiany & & Jednodniowe & Wielokr & nego użytku \\
\hline Materiał & hydrożel & Si-Hy & hydrożel & Si-Hy \\
\hline Białka & $45 \%$ & $13 \%$ & $71 \%$ & $22 \%$ \\
\hline Lipidy & $18 \%$ & $49 \%$ & $21 \%$ & $69 \%$ \\
\hline Brak osadów & $34 \%$ & $34 \%$ & $7 \%$ & $8 \%$ \\
\hline Inne odpowiedzi & $\begin{array}{l}\text { - Zależy od } \\
\text { pacjenta } \\
\text { - Makijaż }\end{array}$ & $\begin{array}{l}\text { - Zależy od pacjenta } \\
\text { - Nie wiem } \\
\text { - Make-up } \\
\text { - Bardzo rzadko, ale jednak zdarzają } \\
\text { się osady lipidowe }\end{array}$ & $\begin{array}{l}\text { - Nie aplikuję hydro- } \\
\text { żeli }\end{array}$ & - Osady z makijażu \\
\hline
\end{tabular}

W odpowiedziach na pytanie 5. 26\% specjalistów stwierdziło, że zawsze ocenia osady na soczewkach kontaktowych podczas wizyt kontrolnych, 40\% robi to w większości przypadków, 28\% tylko w niektórych przypadkach, a $6 \%$ zadeklarowało, że nie robi tego wcale. 


TABELA 3
\begin{tabular}{l|c|l|c|c} 
Zebrane wyniki (odsetek odpowiedzi) na temat opinii specjalistów dotyczących wpływu osadów lipidowych na komfort i jakość widzenia \\
(pytania 6. i 7.).
\end{tabular}
\begin{tabular}{l|c|l|c} 
Odpowiedź & $\%$ & Odpowiedź & \% \\
\hline Zawsze prowadzą do dyskomfortu & $9 \%$ & Zawsze prowadzą do pogorszenia widzenia & $18 \%$ \\
\hline Czasami prowadzą do dyskomfortu & $\mathbf{8 3} \%$ & Czasami prowadzą do pogorszenia widzenia & $\mathbf{7 5 \%}$ \\
\hline Nie wpływają na komfort & $8 \%$ & Nie wpływają na jakość widzenia & $7 \%$
\end{tabular}

82\% specjalistów uważa, że poszczególne materiały soczewek Si-Hy charakteryzują się różną odpornością na osady lipidowe, przy czym 47\% sądzi, iż różnice te są niewielkie (ryc. 3). 47\% respondentów deklaruje, że odporność materiału soczewki na osady lipidowe jest dla nich istotnym parametrem $\mathrm{w}$ procesie doboru soczewki dla pacjenta (ryc. 4). 67\% polskich ECPs uważa, że producenci powinni opisywać soczewki pod kątem odporności na osady lipidowe (ryc. 5).

\section{RYCINA 3}

\section{Procentowy udział odpowiedzi respondentów na pytanie 8.}

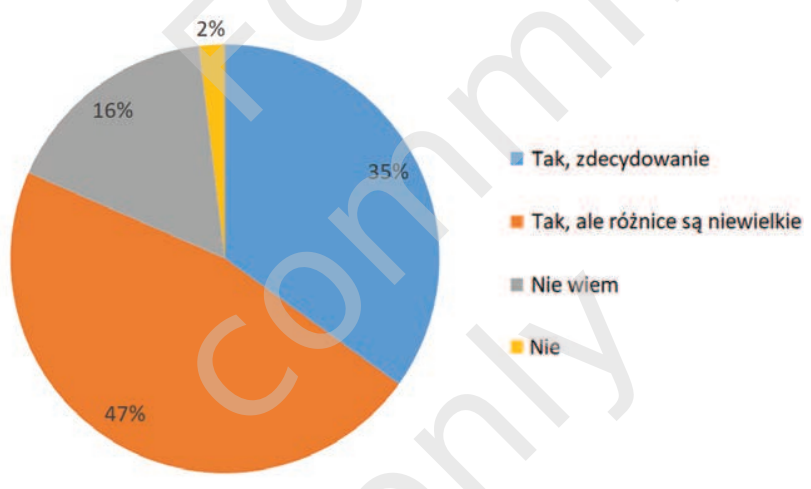

\section{RYCINA 4}

\section{Procentowy udział odpowiedzi respondentów na pytanie 9.}

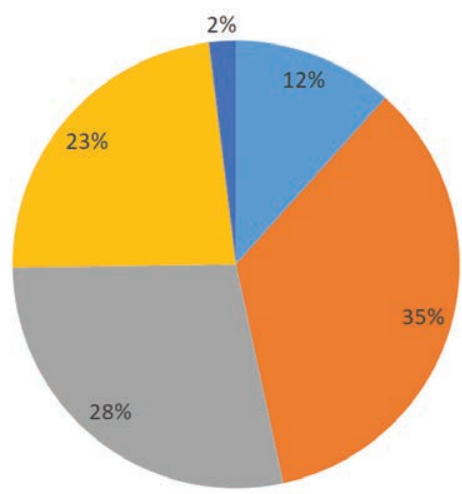

Tak, zdecydowanie

- Tak

- Nie mam zdania

Nie

nie, zdecydowanie

\section{RYCINA 5}

Procentowy udział odpowiedzi respondentów na pytanie 10.

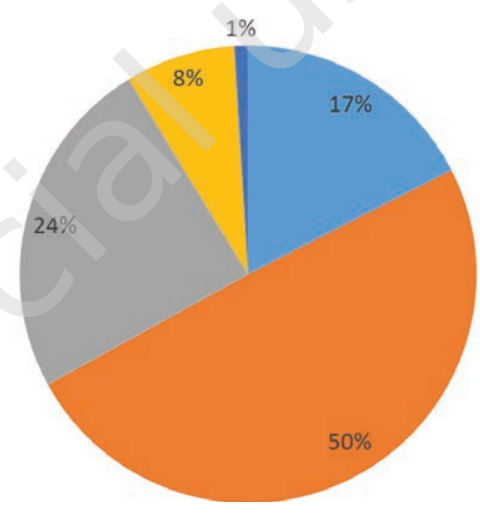

- Tak, zdecydowanie

- Tak

Nie mam zdania

$=\mathrm{Nie}$

- Nie, zdecydowanie

Z kolei $88 \%$ specjalistów zgadza się z tym, że poszczególne płyny do pielęgnacji soczewek kontaktowych mają różną skuteczność w redukcji osadów lipidowych, a 58\% zdecydowanie się z tym zgadza (ryc. 6). 65\% respondentów deklaruje, że skuteczność redukcji osadów lipidowych jest dla nich ważnym parametrem przy wyborze płynu do pielęgnacji soczewek (ryc. 7). 82\% polskich ECPs uważa, że płyny do pielęgnacji soczewek powinny być opisywane przez producentów według ich skuteczności w redukcji osadów lipidowych (ryc. 8).

\section{RYCINA 6}

Procentowy udział odpowiedzi respondentów na pytanie 11.

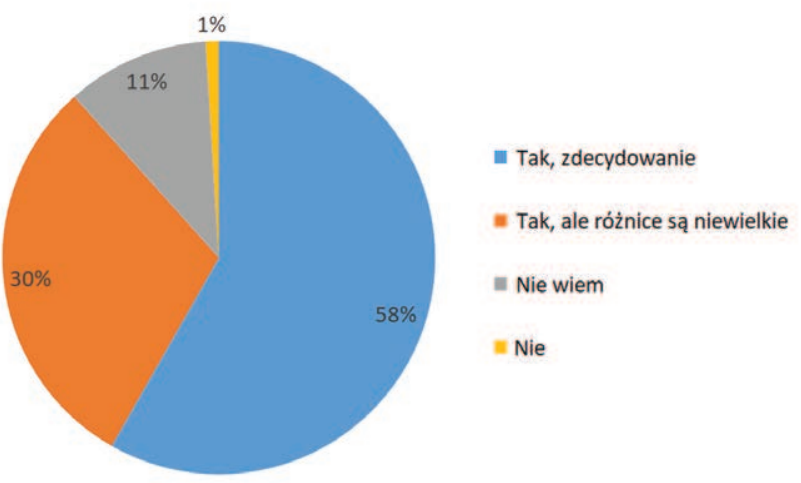




\section{RYCINA ( 7}

Procentowy udział odpowiedzi respondentów na pytanie 12.

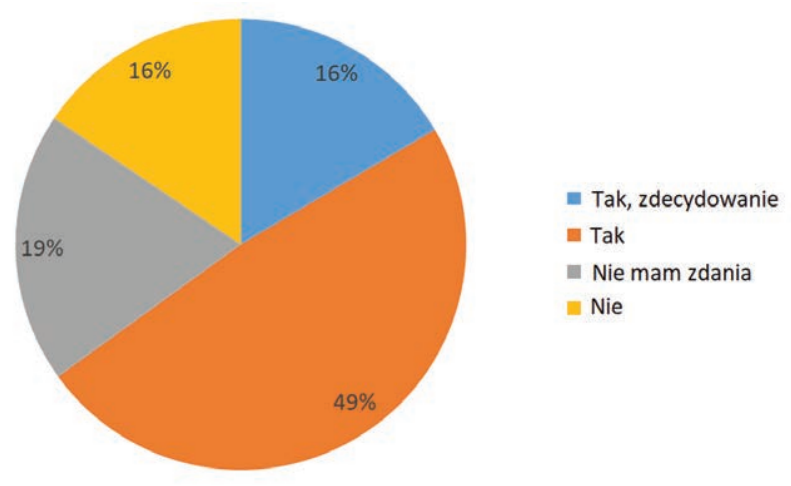

\section{RYCINA 8}

Procentowy udział odpowiedzi respondentów na pytanie 13.

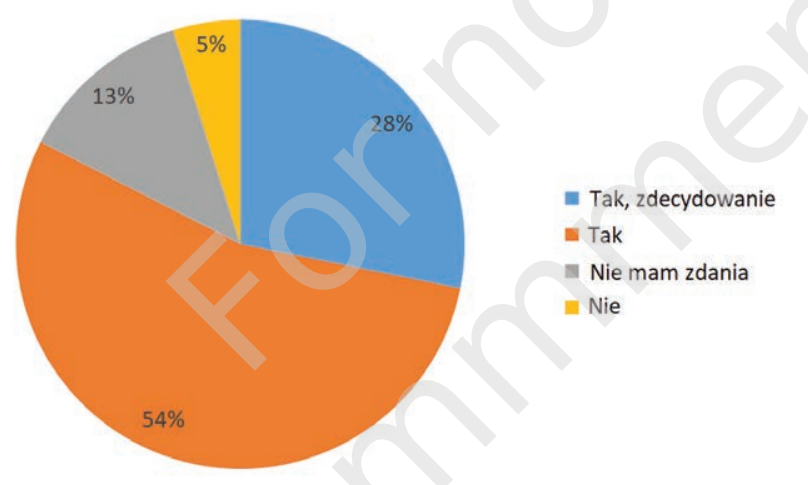

\section{DYSKUSJA}

Odpowiedzi polskich ECPs dotyczące występowania poszczególnych rodzajów osadów na różnych materiałach soczewek są zgodne z danymi literaturowymi. Z tabeli 2 wynika, że osady lipidowe są zgłaszane jako najczęściej występujące na soczewkach $\mathrm{Si}$-Hy, a osady białkowe - jako najczęściej występujące na soczewkach hydrożelowych, przy czym więcej respondentów wskazuje na występowanie takich osadów na soczewkach wielokrotnego użytku niż na soczewkach jednodniowych. W przypadku soczewek jednodniowych 34\% ECPs zgłasza brak osadów, co potwierdza praktyczną stosowaną zasadę, że w przypadku pojawienia się osadów na soczewkach wielokrotnego użytku należy rozważyć zmianę na soczewki jednodniowe [11]. W przypadku większości typów soczewek pojawiły się również odpowiedzi wskazujące na makijaż jako rodzaj osadu, co zostało również opisane w innych publikacjach [12-14].

Wizyta kontrolna jest integralną częścią procesu dopasowywania soczewek kontaktowych. Została ona uwzględniona $\mathrm{w}$ Standardzie badania optometrycznego $i$ dopasowania soczewek kontaktowych, wydanym przez Polskie
Towarzystwo Optometrii i Optyki oraz Polskie Stowarzyszenie Soczewek Kontaktowych. Ocena soczewek została wskazana jako jeden z etapów tej wizyty [15]. Tylko 6\% respondentów stwierdziło, że nie dokonuje oceny osadów na soczewkach podczas wizyty kontrolnej, co sugeruje, iż jest to powszechnie stosowana procedura podczas dopasowywania soczewek.

Wyniki badania pokazują, że polscy ECPs uważają osady lipidowe za potencjalne źródło dyskomfortu użytkowania soczewek kontaktowych, przy czym zdecydowana większość z nich sądzi, iż zdarza się to sporadycznie. Tylko 8\% ankietowanych uważa, że złogi lipidowe w ogóle nie wpływają na komfort użytkowania soczewek (tab. 2). Jednak w literaturze brak jest bezpośrednich dowodów na to, że osady lipidowe mogą powodować dyskomfort [9]. Ponadto większość respondentów stwierdziła, że złogi lipidowe moga prowadzić do pogorszenia jakości widzenia (tab. 2). Większość ankietowanych specjalistów (82\%) zgadza się z tym, że poszczególne materiały soczewek Si-Hy mają różną odporność na powstawanie osadów lipidowych. Jednak 47\% uważa, iż różnice te są niewielkie, co kontrastuje z danymi z piśmiennictwa, które wskazują na duże zróżnicowanie w ilości osadów lipidowych dla poszczególnych materiałów soczewek i sposobów obróbki ich powierzchni [7, 16-20]. Jeszcze więcej specjalistów (88\%), zgadza się z tym, że poszczególne płyny do soczewek kontaktowych mają różną skuteczność w redukcji osadów lipidowych, przy czym 58\% deklaruje, iż zdecydowanie zgadza się z tym stwierdzeniem. Dane literaturowe potwierdzają te opinie [21].

Do celów analizy pytań 9., 10., 12. i 13. wykluczono odpowiedzi „nie mam zdania”. 65\% respondentów ( $\mathrm{n}=74$ ) stwierdziło, że odporność materiału soczewki na powstawanie osadów lipidowych jest dla nich ważna przy wyborze soczewki dla pacjenta. Co więcej, 81\% (n = 83) uznało, że skuteczność redukcji osadów lipidowych jest istotna przy wyborze płynu pielęgnacyjnego. 89\% polskich ECPs (n = 78) uważa, iż producenci powinni opisywać soczewki w zależności od ich odporności na powstawanie osadów lipidowych, a 94\% (n = 90) stwierdziło, że producenci powinni opisywać płyny do pielęgnacji soczewek w zależności od ich skuteczności w redukcji osadów lipidowych.

\section{PODSUMOWANIE}

Polscy ECPs uważają, że ocena osadów jest istotnym etapem w procesie dopasowywania soczewek kontaktowych. Ich obserwacje dotyczące rodzajów osadów na poszczególnych rodzajach soczewek są zgodne z danymi literaturowymi. Zarówno dane literaturowe, jak i odpowiedzi z niniejszej ankiety nie wskazują jednoznacznie na związek pomiędzy osadami lipidowymi na soczewkach a pojawieniem się dyskomfortu i pogorszeniem jakości widzenia. 
Respondenci uważają, że poszczególne soczewki i płyny do ich pielęgnacji różnią się w kontekście ich interakcji z osadami lipidowymi. Ponadto parametry te powinny być brane pod uwagę $\mathrm{w}$ momencie wyboru produktu, aczkolwiek jest to dla nich ważniejsze przy wyborze płynów pie- lęgnacyjnych. Producenci powinni dostarczać informacji na temat odporności soczewek na powstawanie osadów lipidowych oraz skuteczności płynów pielęgnacyjnych w redukcji osadów lipidowych.

\author{
ADRES DO KORESPONDENCJI \\ mgr Tomasz Suliński \\ Alcon Polska \\ 02-674 Warszawa, ul. Marynarska 15 \\ e-mail: tomasz.sulinski@alcon.com
}

\section{ORCID}

Tomasz Suliński - ID - http://orcid.org/0000-0001-9629-3562 Jacek Pniewski - ID - http://orcid.org/0000-0002-6169-120X

\section{Piśmiennictwo}

1. Morgan PB, Woods CA, Tranoudis IG et al. International contact lens prescribing in 2020. Contact Lens Spectr. 2021: 32-8.

2. Millar TJ, Schuett BS. The real reason for having a meibomian lipid layer covering the outer surface of the tear film - A review. Exp Eye Res. 2015; 137: 125-38. http://doi.org/10.1016/j.exer.2015.05.002.

3. Zhou L, Zhao SZ, Koh SK et al. In-depth analysis of the human tear proteome. J Proteomics. 2012; 75(13): 3877-85. http://doi. org/10.1016/J.JPROT.2012.04.053.

4. Yokoi N, Bron AJ, Georgiev GA. The precorneal tear film as a fluid shell: The effect of blinking and saccades on tear film distribution and dynamics. Ocul Surf. 2014; 12(4): 252-66. http://doi.org/10.1016/j.jtos.2014.01.006.

5. McCulley JP, Shine W. A compositional based model for the tear film lipid layer. Trans Am Ophthalmol Soc. 1997; 95: 79-88; discussion 88-93.

6. Mann A, Tighe B. Contact lens interactions with the tear film. Exp Eye Res. 2013; 117: 88-98. http://doi.org/10.1016/j.exer.2013.07.013.

7. Cheung SW, Cho P, Chan B et al. A comparative study of biweekly disposable contact lenses: Silicone hydrogel versus hydrogel. Clin Exp Optom. 2007; 90(2): 124-31. http://doi.org/10.1111/j.1444-0938.2006.00107.x.

8. Nichols JJ. Deposition on silicone hydrogel lenses. Eye Contact Lens 2013: 39: 20-3. http://doi.org/10.1097/ICL.0b013e318275305b.

9. Suliński T, Pniewski J. Interaction of silicone hydrogel contact lenses with lipids - a chronological review. OphthaTherapy. 2020; 7(4): 306-25. http://doi.org/10.24292/01.0T.311220.A.

10. Efron N. History. In: Efron N. Contact Lens Practice. 2018; 3-9.e1. http://doi.org/10.1016/b978-0-7020-6660-3.00001-0.

11. Wagner H. The How and Why of Contact Lens Deposits. Review of Cornea \& Contact Lens. Published 2020. https://www.reviewofcontactlenses.com/article/the-how-and-why-of-contact-lens-deposits.

12. Tsukiyama J, Miyamoto Y, Fukuda M et al. Influence of Cosmetic and Cleansing Products for the Eyes on Soft Contact Lenses. IOVS. ARVO Journals. Published 2010. https://iovs.arvojournals.org/article.aspx?articleid=2368008 (access: 22.10.2021).

13. Tavazzi S, Rossi A, Picarazzi S et. Polymer-interaction driven diffusionof eyeshadow in soft contact lenses. Contact Lens Anterior Eye. 2017; 40(5): 335-9. http://doi.org/10.1016/j.clae.2017.06.003.

14. Luensmann D, Yu M, Yang J et al. Impact of cosmetics on the physical dimension and optical performance of silicone hydrogel contact lenses. Eye Contact Lens. 2015; 41(4): 218-27. http://doi.org/10.1097/ICL.0000000000000109.

15. Standard badania optometrycznego i dopasowania soczewek kontaktowych. http://ptoo.pl/standard-badania (access: 22.10.2021).

16. Jones $L$, Senchyna M, Glasier MA et al. Lysozyme and lipid deposition on silicone hydrogel contact lens materials. Eye Contact Lens. 2003; 29(suppl 1): S75-9. http://doi.org/10.1097/00140068-200301001-00021.

17. Maziarz EP, Stachowski MJ, Liu XM et al. Lipid Deposition on Silicone Hydrogel Lenses, Part I: Quantification of Oleic Acid, Oleic Acid Methyl Ester, and Cholesterol. Eye Contact Lens Sci Clin Pract. 2006; 32(6): 300-7. http://doi.org/10.1097/01.icl.0000224365.51872.6c.

18. Nash WL, Gabriel MM. Ex vivo analysis of cholesterol deposition for commercially available silicone hydrogel contact lenses using a fluorometric enzymatic assay. Eye Contact Lens. 2014; 40(5): 277-82. http://doi.org/10.1097/ICL.0000000000000052.

19. Nash W, Gabriel MM, Mowrey-McKee M. A comparison of various silicone hydrogel lenses; Lipid and protein deposition as a result of daily wear. American Academy of Ophthalmology (AAO); 2010. https://www.aaopt.org/detail/knowledge-base-article/comparison-various-silicone-hydrogel-lenses-lipid-and-protein-deposition-result-daily-wear (access: 22.10.2021). 
Analiza opinii polskich specjalistów ochrony wzroku dotyczących osadów na soczewkach kontaktowych

T. Suliński, J. Pniewski

20. Luensmann D, Omali NB, Suko A et al. Kinetic Deposition of Polar and Non-polar Lipids on Silicone Hydrogel Contact Lenses. Curr Eye Res. Published online 2020. http://doi.org/10.1080/02713683.2020.1755696.

21. Shows A, Redfern RL, Sickenberger W et al. Lipid Analysis on Block Copolymer-containing Packaging Solution and Lens Care Regimens: A Randomized Clinical Trial. Optom Vis Sci. 2020; 97(8): 565-72. http://doi.org/10.1097/OPX.0000000000001553.

Wkład autorów:

Wszyscy autorzy w równym stopniu przyczynili się do powstania artykułu.

Konflikt interesów:

Tomasz Suliński jest pracownikiem firmy Alcon Polska;

Jacek Pniewski nie zgłasza konfliktu interesów.

\section{Finansowanie:}

Tomasz Suliński otrzymuje wynagrodzenie z firmy Alcon.

Etyka:

Treści przedstawione w artykule sa zgodne z zasadami Deklaracii Helsińskiej, dyrektywami EU oraz ujednoliconymi wymaganiami dla czasopism biomedycznych.
Authors' contributions:

All authors contributed equally to the article.

Conflict of interest:

Tomasz Suliński is an employee of the Alcon; Jacek Pniewski declares no conflict of interest.

Financial support:

Tomasz Suliński receives remuneration for his work in the Alcon.

Ethics:

The content presented in the article complies with the principles of the Helsinki Declaration, EU directives and harmonized requirements for biomedical journals. 